\title{
Interpretation of the Peaceful Use of Nuclear Energy in the Nonproliferation Treaty
}

\author{
Mentor Lecaj \\ PhD Cand. ${ }^{1}$, International Law, lustiniaunus Primus- Faculty of Law , Ss. Cyril and Methodius University, Scopje
}

Macedonia

\begin{abstract}
The peaceful use of nuclear program, nuclear non-proliferation and disarmament are the main pillars of the NPT. These three key treaty elements are closely related one to another. The purpose of this article is to explain the necessity of export controls now, who established as international norms, the balance between the use of nuclear material and security from danger activities and noncompliance with international security measure regime. The methodology to be used in this paper, it will be analysis of literature and interpretative methods of international legal acts and declarations of states representatives which are involved in resolving nuclear international issues. Taken in consideration the existing literature on this issue, this paper modestly will fulfill the scientific gap in terms of interpretation of use of nuclear peaceful energy in NPT.
\end{abstract}

Keywords: NPT, Peaceful use, Noncompliance activities

\section{Analyzing Main Pillar of Nonproliferation Treaty}

Despite its flaws and weaknesses, the Treaty on the Non-Proliferation of Nuclear Weapons (NPT) remains an invaluable instrument for international security... There is no alternative but to support and strength NPT ${ }^{2}$

\section{French Committee for Foreign Affair, Defense and Military Forces in Senate}

Security is an elastic and diverse concept that can be understood in different forms, depending on its objects: the perception of threats, the protected values, and the means through which these values can be protected. The changing perception of security threats that already emerged in the 1980s, and ways in which these threats are addressed, has led to comprehensive and scientific studies of security concept. While the multidimensionality of security is now widely acknowledged in the discourse of security, its impacts on and challenges to international law are yet to be fully examined. ${ }^{3}$

Treaty on the Non-Proliferation of Nuclear Weapons, ${ }^{4}$ will be the key discussed issue of the analysis over legal effectiveness of nonproliferation, or better known by all entities, institutions, scholars of the international law and

\footnotetext{
${ }^{1}$ with mentoring of Prof. Dr. Ljubomir Danailov Ferčkoski.

2 Biad, Abdelwahab, Between Shadow and Light: The Treaty on the Non-Proliferation of Nuclear Weapons

Forty Years On, Nuclear Law Bulletin, Nuclear Energy Agency, No 86, Volume 2010/2, pg..5.

${ }^{3}$ Nasu, Hitashi, The Expanded Conception Of Security And International Law: Challenges To The Un Collective Security System, International Security, Amsterdam Law Forum, VU University Amsterdam, 2011, pg. 15.

4 This Treaty was signed on July 1, 1968, in Washington, London and Moscow, ratified and deposited in Washington, London and Moscow on 5 March 1970 and entered into force on March 5, 1970. This consensus between States were regulated and sanctioned by the NonProliferation Treaty (NPT), which entered into force in March 1970. Scientists like Richard Kokoski (researcher at SIPRI -Stockholm International Peace Research Institute for military technology and project for controlling the weapons) argued that the NPT has established a sufficient legal framework of control proliferations of nuclear materials and expertise. More than that, the signatories of this Treaty, vowed not to take any action that would increase the number of countries with nuclear weapons. Treaty without any changes so far assumes that states that do not possess nuclear weapons, and which are parties to the treaty must not produce or purchase nuclear weapons or other explosive nuclear devices. But the existing nuclear-armed states, the treaty does not require and does not oblige to submit their nuclear
} 
international relations field, with the acronym NPT (Non Proliferation Treaty). Before going into details of this binding actinstrument according to general descriptive knowledge within it, it shows that this is an international treaty that aims to prevent the spread of nuclear weapons and technology, promotes cooperation in the peaceful use of nuclear energy and more than that the goal to achieve generally and universally the disarmament of states who possess the nukes. ${ }^{1}$

This is mentioned according to Article III, were each non-nuclear-weapon State Party to the Treaty undertakes to accept safeguards, as set forth in an agreement to be negotiated and concluded with the International Atomic Energy Agency in accordance with the Statute of the International Atomic Energy Agency and the Agency's safeguards system, for the exclusive purpose of verification of the fulfillment of its obligations assumed under this Treaty with a view to preventing diversion of nuclear energy from peaceful uses to nuclear weapons or other nuclear explosive devices. ${ }^{2}$

If we analyze this article mentioned above, then we can conclude that this article does not provides a comprehensive mechanism for verification and evaluation of compliance, to undertake actions on nuclear nonproliferation. Obligations are coming from the non-proliferation provisions in the veracity of the offer in their countries or in their ability to maintain the confidence we all NNWS parties. ${ }^{3}$ But approaching the topic and using the evaluative and historic methodology interpretations, to this disposition contest, and taken in considerations the circumstances in which it was drafted this article, concluded that the time when the NPT was negotiated, is believed to be impossible to detect the presence of a nuclear weapon, which can be transferred clandestinely from one state to another. ${ }^{4}$

The interpretation of this article today has opened scientific debate in international law and international relations field. One of the most interesting debates over the interpretation and understanding of the NPT have to do today are concerns over Article IV of the Treaty: Provisions of this article, which are relating about the peaceful use of nuclear energy. These debates have started as a result of the decision by North Korea, Iran and other states ${ }^{5}$ to use the rights deriving from Article IV, and secretly pursued a program of enrichment of uranium and plutonium, its commitments in reprocessing(uranium) contrary not only to safeguard nuclear agreement (Nuclear Guarantees) under Article III, but given the overall design of the Iranian nuclear program, which has indicia that is designed to provide the capacity and capability to build nuclear weapons, which contradicts the Article II of the NPT. Even diplomatic confrontation, of the parties involved in this case has been particularly sharp since the public announcement of the part of the program to the clandestine transfer of nuclear material by North Korea and Iran. ${ }^{6}$

The article IV, it precise that all parties to the Treaty, has the right to develop nuclear program for peaceful purposes" Nothing in this Treaty shall be interpreted as affecting the inalienable right of all the Parties to the Treaty to develop

weapons, but recommends to those countries to negotiate between them in good faith to eliminate such weapons. For non-nuclear states (NWS Non-Nuclear Weapon State) there is no room for negotiation. Consequently, the treaty has created two classes or groups of states, such as: countries with nuclear weapons and without nuclear weapons. Countries with nuclear weapons consider to be those states who have done the tests before January 1, 1967 For more visit at. Etemikef, Laz, The Politics of nuclear non-Proliferation, Cejiss 3-4/2012 , Pg13-16.

1 Legal aspects, Treaty on the Non-Proliferation of Nuclear Weapons (NPT),http://nuclearenergy.ir/legal-aspects/, 02.04.2016.

2 The Treaty on the Non-Proliferation of Nuclear Weapons ( NPT ), Article, III.

3 Treaty without any changes so far assumes that states that do not possess nuclear weapons, and which are parties to the treaty must not produce or purchase nuclear weapons or other explosive nuclear devices. But the existing nuclear-armed states, the treaty does not require and does not oblige to submit their nuclear weapons, but recommends to those countries to negotiate between them in good faith to eliminate such weapons. For non-nuclear states (NWS NonNnuclear Weapon State) there is no room for negotiation. Consequently, the treaty has created two classes or groups of states, such as: countries with nuclear weapons and without nuclear weapons. Countries with nuclear weapons consider to be those states who have done the tests before January 1, 1967, for more see at. Etemikef Laz, The Politics of nuclear non-Proliferation, Cejiss 3-4/2012, Pg13-16.

${ }^{4}$ Spies, Michael, Essay, Iran and the Limits Of The Nuclear Non-Proliferation Regime, 410 AM. U. INT'L L. REV. SPIES-.DOC 4/8/2007, FQ 410 .

${ }^{5}$ A.Q. Khan has become a pop icon for contemporary proliferation, and is widely blamed for the existence of Pakistan's, Iran's, Libya's, and North Korea's gas centrifuge programs. Technology now dominates how policymakers think about proliferation, and many share the view that, "with the exception of a few advanced industrialized countries, a state's ability to build nuclear weapons generally hinges on its ability to and an international supplier." For more see at Kemp,R.Scott. "The Nonproliferation Emperor Has No Clothes."International Security 38, no. 4 (April 2014) , pg, 39-40.

${ }^{6}$ Ford, Christopher A.,Nuclear Technology Rights and Wrongs:The NPT, Article IV, and Nonproliferation , fq 2-3- 
research, production and use of nuclear energy for peaceful purposes without discrimination and in conformity with Articles I and II of this Treaty." More over the par. 2. of article IV states that" All the Parties to the Treaty undertake to facilitate, and have the right to participate in, the fullest possible exchange of equipment, materials and scientific and technological information for the peaceful uses of nuclear energy. Parties to the Treaty in a position to do so shall also co-operate in contributing alone or together with other States or international organizations to the further development of the applications of nuclear energy for peaceful purposes, especially in the territories of non-nuclear-weapon States Party to the Treaty, with due consideration for the needs of the developing areas of the world." 2

All those who have dealt with the interpretation of the Treaty, agree that the core of NPT embodies a strong commitment to share the benefits that nuclear technology can bring to mankind. This important issue is quite significant even though Article IV is controversial in contemporary diplomatic and political debates. ${ }^{3}$

Taken in consideration the legal framework regarding the security and use of peaceful nuclear power, two recent decades, since the explosion in Chernobyl, the international community has taken many actions to build a harmonized infrastructure, effective, transparent, organizing and exploiting joint forums cooperation between countries (such as the, Six party talksNorth Korea Case, P5 + 1 -Iran case, IAEA to fulfill such obligation). However, the mankind and states are in cross road, and that the benefits from peaceful use of nuclear energy and different reality we face from terrorism phenomenon. We are witness of many statements about ambitions of terrorist groups to put hands on WMD, as well as detection of secret nuclear program, supply networks and urgency of increasing a black market with nuclear materials and equipment's. It is necessity of the higher level efforts to cooperate by all key stakeholders. ${ }^{4}$

More over the Article V, state that, States Parties are encouraged to take appropriate measures to ensure that "the potential benefits from any application peaceful nuclear explosions will be available for countries on a nondiscriminatory basis that does not possess nuclear weapons, which are Parties to the Treaty."Each Party to the Treaty undertakes to take appropriate measures to ensure that, in accordance with this Treaty, under appropriate international observation and through appropriate international procedures, potential benefits from any peaceful applications of nuclear explosions will be made available to non-nuclear-weapon States Party to the Treaty on a non-discriminatory basis and that the charge to such Parties for the explosive devices used will be as low as possible and exclude any charge for research and development. Non-nuclear-weapon States Party to the Treaty shall be able to obtain such benefits, pursuant to a special international agreement or agreements, through an appropriate international body with adequate representation of non-nuclear-weapon States. Negotiations on this subject shall commence as soon as possible after the Treaty enters into force. Non-nuclearweapon States Party to the Treaty so desiring may also obtain such benefits pursuant to bilateral agreements." 5

\section{Effort of International Community to Deal with Non Proliferation}

Challenges appear today had changed the view to international community day by day, in creating, more agencies, groups of interest, associations, and among the best known today is the Nuclear Suppliers Group (NSG- The Nuclear Suppliers Group). ${ }^{6}$

This is a countries group of nuclear supplier, which aims to contribute to non-proliferation efforts by developing guidelines for nuclear experts or exports related to nuclear transport. Member states of the NSG argue that its guidelines aim to ensure that nuclear trade for peaceful purposes does not contribute to the spread of nuclear weapons and other nuclear explosive

\footnotetext{
1 The Treaty on the Non-Proliferation of Nuclear Weapons ( NPT ), Article, IV, Par 1.

2 NPT, Article, IV, Par 2.

3 Ford, Christopher A. Nuclear Technology Rights and Wrongs:The NPT, Article IV, and Nonproliferation , pg 3-4., https://www.nonproliferation.org/wp-content/uploads/npr/143ford.pdf, 02, 04.2016.

${ }^{4}$ Rautenbach, Johan, Tonsauser, Wolfram, Wetherall, Anthony, Overview of the International Legal Framework Governing the Safe and Peaceful Uses of Nuclear Energy OECD, 2006 .pg. 34-35.

${ }^{5}$ The Treaty on the Non-Proliferation of Nuclear Weapons ( NPT ), Article, V, Par 1.

${ }^{6}$ The members of the NSG are: Argentina, Australia, Austria, Belarus, Belgium, Brazil, Bulgaria, Canada, China, Croatia, Cyprus, Czech Republic, Denmark, Estonia, Finland, France, Germany, Greece, Hungary, Iceland, Ireland, Italy, Japan, Kazakhstan, Republic of Korea, Latvia, Lithuania, Luxembourg, Malta, Netherlands, New Zealand, Norway, Poland, Portugal, Romania, Russian Federation, Slovakia, Slovenia, South Africa, Spain, Sweden, Switzerland, Turkey, Ukraine, the United Kingdom, and the United States .
} 
devices, while at the same time does not hinder international trade and cooperation in the nuclear field. The first part of the NSG guidelines governs the export of items that are specifically designed for nuclear use. These include: (i) nuclear material; (li) nuclear reactors and equipment for this purpose; (lii) non-nuclear material for reactors;(Iv) plant and equipment for the reprocessing, enrichment and conversion of nuclear material and the production of fuel and heavy water production; and (v) technology associated with each of the items mentioned above. The second part of guidelines regulates the export of nuclear items and technologies for double exploitation where these tools can make a major contribution to a cycle outside the safeguards of nuclear fuel or nuclear explosive activity, but not for the purpose of nuclear, but for peaceful purposes, for example. in the industry. ${ }^{1}$

Also one of the main tasks that IAEA has, under the statute is to increase activity and its contribution to the peaceful use of nuclear energy, preservation of health and prosperity around the globe. Moreover, it will ensure as far as possible, continuously in giving the assistance for the peaceful exploitation, and not be used for military purposes. ${ }^{2}$ Also the agency is authorized to encourage and assist research, development and utilization of nuclear energy for peaceful exploitation in worldwide. The Agency has an obligation to act as a mediator when required by it, with the purpose of providing services, supply material or devices in buildings by one member of agency to another member. Also this institution carries out activities or services in research, development or practical application of nuclear energy for peaceful purposes. ${ }^{3}$

Interpretation and meaning of the provisions on the peaceful use of the Treaty, it was debated for many years between those who defend the right to access technology and those who read NPT as reflect of strong commitment in sharing the nuclear benefits and specific treatment of requests for access to technology. From these two camps, scholars from the last group, who belong to the school "safeguard ability", provide the strongest argument ${ }^{4}$

\section{Conclusion}

Having in mind that the core of international regime of nonproliferation it remains today the NPT. Its main purpose is the safe and peaceful use of nuclear energy. So far in recent two decades have been revealed a illegally nuclear material in Iraq, Syria, Libya, Iran and North Korea. The International Community must take serious efforts and significant step to establish a harmonized effect, efficient and transparent infrastructure. One of them it can be mentioned a forum for international cooperation among states, international organizations, such as the IAEA have been "efficient" to fulfill its goal to deal with new challenges cases appeared in our decade. But now days it appears a new reality concerns in era we are living. In one side it is a nuclear energy production and technology. On the other side it appears the rise of terrorism and declared ambitions of terrorists to acquire and use of Weapon of Mass Destructions, so that more efforts must be taken as diplomatic effort, political and other institutional steps to reduce the highly risk from illegally nonproliferation.

Still today remains one of the most interesting debates concerns provisions of NPT concerning the peaceful uses of nuclear energy .and nonproliferation. These debates have been increased as a result of both north Korea and Iran's decision to adopt the cause of norms "rights" while secretly pursuing a program of uranium enrichment and plutonium reprocessing in violation not just of its nuclear safeguards agreements under Articles of NPT but as well violation the safeguard agreements which are obliged to respect and apply as an agreement reached according to order be given to the parties who are member of NPT. Apparently it shows that North Korea and Iran's nuclear program was designed to give it the ability to build nuclear weapon. The diplomatic confrontation has been especially acute since the embarrassing public nuclear test and withdrew from NPT of North Korea and revelation in Iran's clandestine nuclear program in August 2002.

\footnotetext{
1 Gandenberger, Mia, Fihn, Beatrice, and Irsten, Gabriella, Reaching Critical Will, , Rue De Varembe, 1211, Geneve, 29 June, 2011, pq. 8-9.

${ }^{2}$ IAEA, Statute as amended up to 23 February, 1989, Article, I.

3 IAEA, Statute as amended up to 23 February, 1989, Article, II. Par. 1.

${ }^{4}$ Christopher A. Ford, Nuclear Technology Rights and Wrongs: The NPT, Article IV, and Nonproliferation, pq. 2.
} 
The international community must agreed that limiting the spread of sensitive nuclear technology is in the interests of all states and making this choice will involve substantial practical benefits to countries looking to develop peaceful nuclear energy programs.

\section{Bibliography}

[1] Biad, Abdelwahab, Between Shadow and Light: The Treaty on the Non-Proliferation of Nuclear Weapons, Forty Years On, Nuclear Law Bulletin, Nuclear Energy Agency, No 86 , Volume 2010/2.

[2] Christopher A. Ford, Nuclear Technology Rights and Wrongs: The NPT, Article IV, and Nonproliferation.https://www.google.com/webhp?sourceid=chromeinstant\&ion=1\&espv=2\&ie=UTF $8 \# q=$ interpretation+of+Non+Proliferation+Treaty+Pdf\&start=10.

[3] Etemikef, Laz, The Politics of nuclear non-Proliferation, Cejiss 3-4/2012 Forty Years On, Nuclear Law Bulletin, Nuclear Energy Agency, No 86, Volume 2010.

[4] Gandenberger, Mia, Fihn, Beatrice, and Irsten, Gabriella, Reaching Critical Will, Rue De Varembe, 1211, Geneve, 29 June, 2011.

[5] IAEA, Statute as amended up to 23 February, 1989.

[6] Rautenbach, Johan, Tonsauser, Wolfram, Wetherall, Anthony, Overview of the International Legal Framework Governing the Safe and Peaceful Uses of Nuclear Energy OECD, 2006.

[7] Spies, Michael, Essay, Iran and the Limits Of The Nuclear Non-Proliferation Regime, 410 AM. U. INT'L L. REV. SPIES-.DOC 4/8/2007.

[8] The Treaty on the Non-Proliferation of Nuclear Weapons ( NPT ), 1968. 